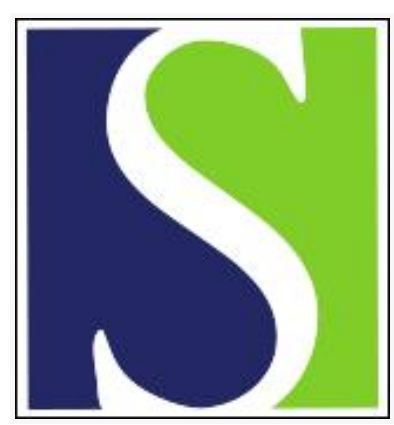

Scand J Work Environ Health 1990;16(5):372-378

https://doi.org/10.5271/sjweh.1771

Issue date: 00 Oct 1990

Uptake, distribution and elimination of alpha-pinene in man after exposure by inhalation.

by Falk AA, Hagberg MT, Lof AE, Wigaeus-Hjelm EM, Wang ZP

Affiliation: Division of Work and Environmental Physiology, National Institute of Occupational Health, Solna, Sweden.

This article in PubMed: www.ncbi.nlm.nih.gov/pubmed/2255878

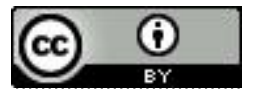




\title{
Uptake, distribution and elimination of $\alpha$-pinene in man after exposure by inhalation
}

\author{
by Agneta A Falk, MSc, ${ }^{1}$ Mats T Hagberg, MD, PhD, ${ }^{1}$ Agneta E Löf, PhD, ${ }^{1}$ \\ Ewa M Wigaeus-Hjelm, PhD, ${ }^{1}$ Wang Zhiping, MD $^{2}$
}

\begin{abstract}
FALK AA, HAGBERG MT, LÖF AE, WIGAEUS-HJELM EM, ZHIPING W. Uptake, distribution and elimination of $\alpha$-pinene in man after exposure by inhalation. Scand $J$ Work Environ Health 1990;16: $372-8$. The toxicokinetics of $\alpha$-pinene were studied in human volunteers exposed by inhalation $(2 \mathrm{~h}$, $50 \mathrm{~W}$ ) in an exposure chamber on four occasions. The exposures were about 10,225 , and $450 \mathrm{mg} / \mathrm{m}^{3}$ $(+)-\alpha$-pinene and $450 \mathrm{mg} / \mathrm{m}^{3}(-)$ - $\alpha$-pinene. The relative pulmonary uptake was about $60 \%$ for the higher exposures, and total uptake increased linearly with increasing exposure. The total blood clearance was high, about $1.11 \cdot \mathrm{h}^{-1} \cdot \mathrm{kg}^{-1}$. After the exposure was terminated, less than $0.001 \%$ of the total uptake was eliminated unchanged in the urine and about $8 \%$ in exhaled air. A long half-time in poorly perfused tissues indicates a high affinity to adipose tissues. There was a statistically significant exposureresponse relationship among five subjects who experienced irritation. Short-time exposure to $\alpha$-pinene did not give rise to acute changes in lung function 20 min after the exposure.
\end{abstract}

Key terms: central nervous system effects, human exposure, irritative symptoms, pulmonary function, terpenes, toxicokinetics.

Terpenes occur naturally in pine trees and certain bushes. The major components are $\alpha$-pinene, $\beta$-pinene and 3-carene; the proportions vary with season, species, and locality (1). Terpenes are present in gases liberated during the sawing or processing of fresh wood and form a potential exposure for workers in sawmills $(2,3)$. They are also present as by-products in sulfate extraction processes and in solvents. For turpentine, a mixture of several terpenes, the Swedish occupational exposure limit is $450 \mathrm{mg} / \mathrm{m}^{3}$, but for single terpenes there is no hygienic standard in Sweden.

The high solubility of terpenes in blood and adipose tissue should imply a high respiratory uptake and accumulation in adipose tissues (4). The respiratory and percutaneous uptake of terpenes has been observed in man $(5,6)$, but no quantitative study was found regarding absorption. In rat, terpenes accumulate in peripheral fat, kidneys, and brain $(7,8)$. Slow renal elimination was observed in an acutely poisoned patient (9). Terpenes may irritate the skin and mucous membranes $(1,5)$, and prolonged exposure may result in allergic contact dermatitis $(10,11)$ or chronic lung function impairment $(2,3,12)$. Almost all of the literature found regarding the effects of terpenes discusses turpentine, and not the single terpenes. In our study we wanted to expose subjects to a single terpene at different exposure levels, and we chose the most common terpene, $\alpha$-pinene.

\footnotetext{
1 Division of Work and Environmental Physiology, National Institute of Occupational Health, Solna, Sweden.

2 Division of Lung Physiology, National Institute of Occupational Health, Solna, Sweden.
}

Reprint requests to: Ms A Falk, National Institute of Occupational Health, S-171 84 Solna, Sweden.
The main purposes of the present study were to determine the uptake, distribution, and elimination of $\alpha$-pinene in man and to study pulmonary function and measure symptoms by subjective ratings during brief experimental exposures to different concentrations of $\alpha$-pinene.

\section{Subjects and methods}

\section{Subjects}

Eight healthy men, with an average age of 31 (range 24-39) years and an average weight of 80 (range 7196) $\mathrm{kg}$ participated in the study. The subjects were not occupationally exposed to solvents and were instructed to refrain from drinking alcoholic beverages for at least $2 \mathrm{~d}$ before each exposure. All the participants were given a general medical examination preceding the experiment and were judged to be healthy. The study was approved by the Regional Ethical Committee at the Karolinska Institute, Solna, Sweden.

\section{Experimental design}

The subjects were exposed to $\alpha$-pinene $(98 \%$ Aldrich, Federal Republic of Germany) for 2 h during light physical exercise ( $50 \mathrm{~W}$ on a bicycle ergometer) in an exposure chamber. The concentrations were 450,225 , or $10 \mathrm{mg} / \mathrm{m}^{3}(+)-\alpha$-pinene or $450 \mathrm{mg} / \mathrm{m}^{3}(-)-\alpha$ pinene. Two subjects were exposed on each occasion. The sequence of the exposure concentrations was based on a Latin square $4 \times 4$ design. The subjects were informed of the experimental design but were not told the exposure sequence.

The volume of the chamber was $12 \mathrm{~m}^{3}$. The air was changed 10 times/h. To prevent the solvent from leak- 
ing from the chamber into the surroundings, the inlet flow was $115 \mathrm{~m}^{3} / \mathrm{h}$ and the outlet flow was $135 \mathrm{~m}^{3} / \mathrm{h}$. The solvent was injected into the inflowing air stream by means of a high-performance liquid chromatographic pump (Gilson 302).

\section{Toxicokinetic measurements and analysis}

The solvent concentration in the chamber was continuously monitored at atmospheric pressure by an infrared spectrophotometer (Miran 80) equipped with a $20-\mathrm{m}$ thermostated $\left(45^{\circ} \mathrm{C}\right)$ gas cell. Measurements were made at $3.36 \mu \mathrm{m}$, with $3.60 \mu \mathrm{m}$ as the reference wavelength. The air was sampled from the upper central section of the chamber. The $\alpha$-pinene concentration did not vary more than $4 \%$ during a 2 -h exposure period.

The total pulmonary uptake of $\alpha$-pinene during each exposure period was calculated as the difference between the total amount of solvent in the inhaled and exhaled air. The exhaled air was collected for each individual in polyester-laminated aluminum foil bags at regular intervals during the exposures, four periods of $4 \mathrm{~min}$ each. The expired volume was measured in a balanced spirometer, and the $\alpha$-pinene concentration was determined as described for the concentration in the chamber. The mean value of these four sampling periods was used to calculate the total $\alpha$-pinene uptake during the entire exposure period. During the exposures the subjects' heart rates were continuously recorded with a heart-rate meter (Sport Tester PE 3000, Polar Electro, Finland).

Capillary blood $(200 \mu \mathrm{l})$ was sampled from a prewarmed fingertip at selected intervals for the determination of $\alpha$-pinene in the blood. During the exposure the subjects held out one hand through a closable hole (diameter $9 \mathrm{~cm}$ ) in the wall. The blood samples were transferred to gas-tight head-space vials (22.4 $\mathrm{ml}$ ) and capped immediately with teflon-lined membranes. The head-space air of the blood samples was analyzed automatically on a gas chromatograph (Perkin Elmer 8700) equipped with a head-space autosampler (Perkin Elmer HS-101), a flame-ionization detector, and a polar column (Supelcowax 10,30 m). The samples were thermostated for $20 \mathrm{~min}$ at $37^{\circ} \mathrm{C}$. The injector temperature was $170^{\circ} \mathrm{C}$, and the detector temperature was $240^{\circ} \mathrm{C}$. The initial column temperature was $80^{\circ} \mathrm{C}$; after $2 \mathrm{~min}$ it was increased by $5^{\circ} \mathrm{C} / \mathrm{min}$ to $100^{\circ} \mathrm{C}$ and then by $25^{\circ} \mathrm{C} / \mathrm{min}$ to $210^{\circ} \mathrm{C}$. Nitrogen at a flow of $5 \mathrm{ml} / \mathrm{min}$ was used as the carrier gas. The concentration of $\alpha$-pinene in the head-space air was determined by comparison with individual standard curves that were prepared in the same concentration range after the addition of $\alpha$-pinene to blood samples taken before the exposures. The detection limit of the experiment was $10 \mathrm{nmol} / \mathrm{l}$, and the relative error of the method within the concentration range, based on 10 double samples, was $2 \%$.
All the urine from all the subjects was collected in glass bottles before exposure and $0.5,4,11$, and $21 \mathrm{~h}$ after the termination of exposure, and the volumes were measured. In the determination of the urine concentration of the unmetabolized $\alpha$-pinene, $2 \mathrm{ml}$ from each urine sample was put in a head-space vial and analyzed by the same method used for the blood samples. The concentration of $\alpha$-pinene was determined by comparison with individual standard curves prepared in the same concentration range after the addition of $\alpha$-pinene to urine samples taken before the exposure.

Exhaled air (samples of about $20 \mathrm{l}$ ) was collected after the exposure $(5,15,25,85,150$, and $230 \mathrm{~min}$ after the termination of exposure) for the determination of the respiratory elimination of unmetabolized solvent. The air was collected and analyzed as described for the samples taken during the exposure.

\section{Kinetic calculations}

Individual semilogarithmic plots of blood concentration versus time were treated by the method of residuals in order to resolve the curves into a linear terminal phase of slope $\gamma(250-1300 \mathrm{~min}$ after exposure), a linear middle phase of slope $\beta$ ( $20-240 \mathrm{~min}$ after exposure), and a linear initial phase of slope $\alpha(0-15$ $\mathrm{min}$ after exposure). The half-times for the three phases were calculated by linear regression of the log-linear time curve of the blood concentration within each interval with the later phase(s) substracted. The blood clearance $(\mathrm{Cl})$ was calculated as the quotient between the total uptake (dose) and the area under the blood concentration versus the time curve (AUC) and adjusted for body weight (13). The following two clearance values were calculated: $\mathrm{Cl}_{4 \mathrm{~h}}$, from values measured up to about $4 \mathrm{~h}$ after the termination of exposure, and $\mathrm{Cl}_{21 \mathrm{~h}}$, from values measured up to about $21 \mathrm{~h}$ after the termination of exposure. The AUC was calculated from the onset of exposure to the time of the last blood sample by the trapezoidal rule and thereafter to infinity as the quotient between the line estimate of the $\alpha$-pinene concentration in blood at the end of the sampling period and the slope calculated from the linear regression of the log-linear time curve of the blood concentration in the last phase.

The amount of solvent exhaled after the termination of exposure was estimated from the area below the excretion rate in expired air versus the time curve. AUC from the end of exposure to infinity was estimated as described for the blood samples.

\section{Ratings of symptoms}

Before, during, and after each exposure the subjects rated the intensity of irritation for the eyes, nose, and throat and the effects on the central nervous system (CNS) on a $100-\mathrm{mm}$ visual analogue scale (VAS) from no effect to almost unbearable. 


\section{Pulmonary function}

The forced expiratory volume in $1 \mathrm{~s}\left(\mathrm{FEV}_{1,0}\right)$, vital capacity (VC), peak expiratory flow (PEF), residual volume (RV), mean expiratory flow at $50 \%$ of the VC $\left(\mathrm{MEF}_{50}\right)$, airway resistance (Raw), and conductance (sGaw) were measured in a pressure-variable type of body plethysmograph (Jaeger Masterlab, Erich Jaeger $\mathrm{GmbH}$, Würzburg, Federal Republic of Germany), equipped with a pneumotachograph system for the forced expiratory volume measurements. The preexposure measurements were done before, but on the some day as, the first exposure. The postexposure values were obtained between 20 and $30 \mathrm{~min}$ after the subjects left the exposure chamber.

\section{Statistical evaluation}

An analysis of variance (ANOVA) was used to analyze the subjective ratings given by all the subjects. The respiratory parameters were analyzed both with the Wilcoxon signed rank test and Student's t-test for paired analyses (two-sided tests).

Unless otherwise stated the results have been presented as mean values and standard deviations.

\section{Results}

The relative uptake of $(+)$ - and ( $(-)-\alpha$-pinene during $2 \mathrm{~h}$ of exposure averaged $59 \%$ of the amount supplied for the two higher concentrations (table 1). The absolute uptake increased linearly with the exposure concentration. During the exposure the concentrations of $\alpha$-pinene in the arterial blood first increased rapidly and then leveled off towards the end of exposure (figure 1). The mean concentration in the blood at the termination of exposure increased linearly with an increasing exposure concentration (figure 2). The elimination from the blood was considered triphasic during the time studied (figure 3$)$. The half-times $\left(t_{1 / 2}\right)$ of $(+)$ - and (-)- $\alpha$-pinene were 4.8 and $5.6 \mathrm{~min}$, respectively, for the initial $(\alpha)$ phase; 38 and $40 \mathrm{~min}$, respectively, for the rapid elimination ( $\beta$ ) phase; and 695 and
$555 \mathrm{~min}$, respectively, for the slow elimination $(\gamma)$ phase (table 2). There was no difference in $\mathrm{Cl}_{2 \mathrm{~h}}$ between (+)- and (-)- $\alpha$-pinene, 1.1 and $1.21 \cdot \mathrm{kg}^{-1}$ $\cdot \mathrm{h}^{-1}$, respectively (table 2 ). The $\mathrm{Cl}_{4 \mathrm{~h}}$ was calculated for the medium exposure $\left(225 \mathrm{mg} / \mathrm{m}^{3}\right)$; it was virtually the same as the $\mathrm{Cl}_{4 \mathrm{~h}}$ for $450 \mathrm{mg} / \mathrm{m}^{3}$. The respiratory elimination of $(+)$ - and $(-)$ - $\alpha$-pinene after exposure was 7.7 and $7.5 \%$, respectively, of the total uptake (table 1). Less than $0.001 \%$ of the total dose of $\alpha$-pinene was excreted unchanged in the urine within $0.5 \mathrm{~h}$ after the exposure, and the individual variations were high. In the urine samples collected more than $0.5 \mathrm{~h}$ after the exposure, the levels were below the detection limit $(10 \mathrm{nmol} / \mathrm{l})$.

Five subjects experienced irritation of their eyes, nose, and throat during the high exposure. Their responses indicated a statistically significant $\left(\mathrm{F}_{2,9}=\right.$ $36.2, \mathrm{P}<0.001$ ) exposure-response relationship (figure 4).

The results of the lung function tests are shown in table 3. All the pretest lung function values were within normal limits. Only minimal changes were found in the postexposure measurements, and the tendency of change was towards increased bronchial diameter rather than bronchoconstriction, but the changes in the mean values were not statistically significant.

\section{Discussion}

As was expected from its relatively high solubility in blood and fat, determined in vitro (4), the uptake of inhaled $\alpha$-pinene was high. The average relative uptake of $\alpha$-pinene, of the two higher concentrations, was $59 \%$ (table 1), lower than that for styrene $(68 \%$ ) but higher than that for toluene ( $49 \%$ ) in similar experiments $(14,15)$. The partition coefficients between the blood and air for toluene and $\alpha$-pinene are of the same magnitude, while the corresponding coefficient for styrene is higher $(4,16)$. Metabolic rate and fat solubility may be other reasons for the differences in the relative uptake between the three solvents. At

Table 1. Experimental results from 2-h exposures of eight subjects to $(+)-\alpha$-pinene concentrations of 450,225 , and $10 \mathrm{mg} / \mathrm{m}^{3}$ and to a $(-)-\alpha$-pinene concentration of $450 \mathrm{mg} / \mathrm{m}^{3}$ during physical exercise at a work load of $50 \mathrm{~W}$. ( $\dot{\mathrm{V}}_{\mathrm{E}} \mathrm{BTPS}=$ pulmonary ventilation, $\mathrm{RE}=$ cumulative respiratory excretion after end of exposure, UE = cumulative urinary excretion of $\alpha$-pinene up to $0.5 \mathrm{~h}$ postexposure)

\begin{tabular}{|c|c|c|c|c|c|c|c|c|c|c|c|c|c|c|}
\hline \multirow{3}{*}{ Exposure } & \multicolumn{4}{|c|}{$\dot{\mathrm{V}}_{\mathrm{E}} \mathrm{BTPS}(1 / \mathrm{min})$} & \multirow{3}{*}{$\begin{array}{c}\text { Heart } \\
\text { rate } \\
\text { (beats/ } \\
\text { min) }\end{array}$} & \multirow{2}{*}{\multicolumn{2}{|c|}{$\begin{array}{c}\text { Given } \\
\text { amount }^{\mathrm{a}} \\
\text { (mmol) }\end{array}$}} & \multirow{2}{*}{\multicolumn{2}{|c|}{$\begin{array}{c}\text { Uptake }^{a} \\
(\%)\end{array}$}} & \multirow{2}{*}{\multicolumn{2}{|c|}{$\begin{array}{l}\text { Uptake }^{\mathrm{a}} \\
\text { (mmol) }\end{array}$}} & \multirow{3}{*}{$\underset{(\mathrm{mmol})}{\mathrm{RE}^{\mathrm{b}}}$} & \multirow{2}{*}{\multicolumn{2}{|c|}{$\begin{array}{c}\mathrm{UE}^{\mathrm{c}} \\
(\mu \mathrm{mol})\end{array}$}} \\
\hline & \multicolumn{2}{|c|}{$0-120 \mathrm{~min}$} & \multicolumn{2}{|c|}{$121-360 \mathrm{~min}$} & & & & & & & & & & \\
\hline & Mean & SD & Mean & SD & & Mean & $S D$ & Mean & SD & Mean & SD & & Mean & SD \\
\hline \multicolumn{15}{|l|}{$(+)-\alpha$-pinene } \\
\hline $\begin{array}{l}450 \mathrm{mg} / \mathrm{m}^{3} \\
225 \mathrm{mg} / \mathrm{m}^{3} \\
10 \mathrm{mg} / \mathrm{m}^{3}\end{array}$ & $\begin{array}{l}25.8 \\
25.1 \\
25.2\end{array}$ & $\begin{array}{l}4.5 \\
3.8 \\
4.8\end{array}$ & $\begin{array}{l}16.2 \\
17.2 \\
16.6\end{array}$ & $\begin{array}{l}5.4 \\
4.1 \\
4.1\end{array}$ & $\begin{array}{l}88 \\
87 \\
87\end{array}$ & $\begin{array}{l}9.3 \\
5.1 \\
0.22\end{array}$ & $\begin{array}{l}0.5 \\
0.3 \\
0.01\end{array}$ & $\begin{array}{l}58 \\
60 \\
40\end{array}$ & $\begin{array}{l}5.3 \\
3.9 \\
10\end{array}$ & $\begin{array}{l}5.4 \\
3.0 \\
0.08\end{array}$ & $\begin{array}{l}1.3 \\
0.8 \\
0.02\end{array}$ & $\begin{array}{l}0.42 \\
\cdots \\
\cdots\end{array}$ & $\begin{array}{l}0.032 \\
0.008\end{array}$ & $\begin{array}{l}0.005 \\
0.005\end{array}$ \\
\hline \multicolumn{15}{|l|}{$(-)-\alpha \cdot$-pinene } \\
\hline $450 \mathrm{mg} / \mathrm{m}^{3}$ & 25.7 & 2.3 & 16.0 & 4.8 & 88 & 9.6 & 0.3 & 58 & 5.9 & 5.6 & 0.8 & 0.42 & 0.018 & 0.031 \\
\hline
\end{tabular}

a Period 0-120 min.

b Period $120-\infty \mathrm{min}$.

c Period $0-150 \mathrm{~min}$. 


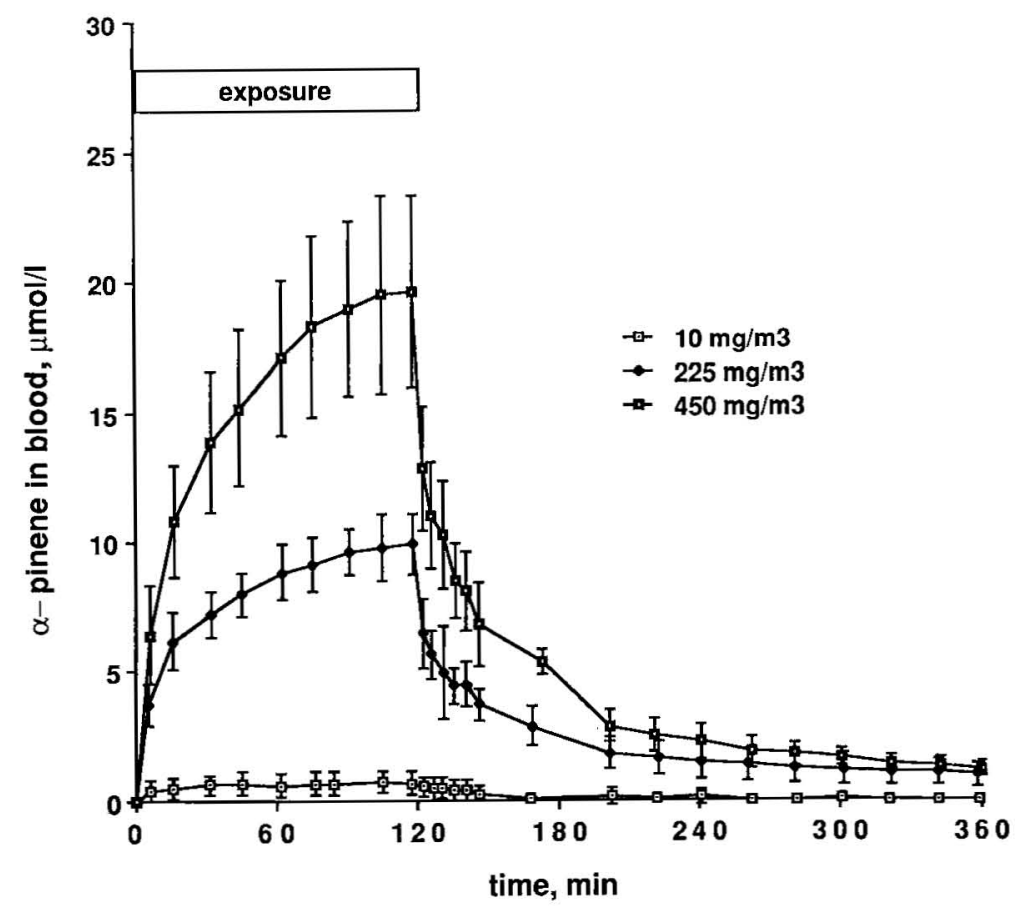

Figure 1. Concentrations of $\alpha$-pinene in capillary blood during and after exposure to $\alpha$-pinene at three different exposure levels $(2 \mathrm{~h}, 50 \mathrm{~W})$. The mean values and standard deviations for eight persons are given.

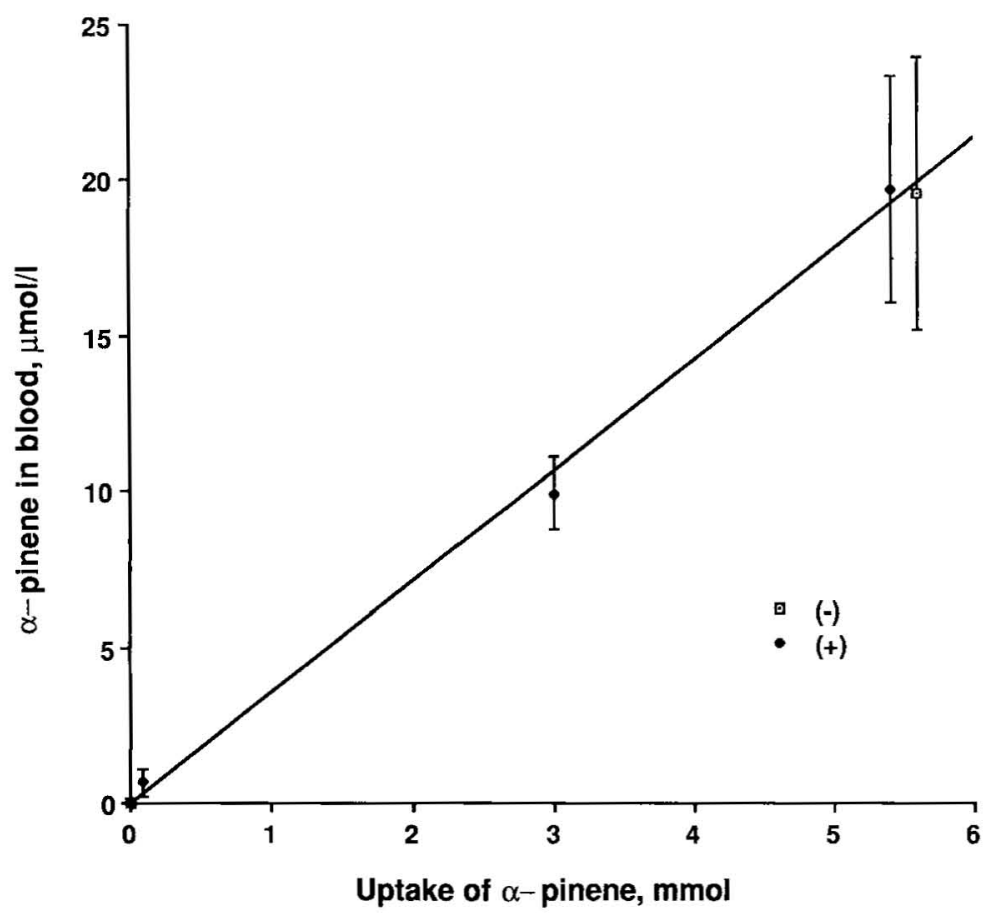

Figure 2. Concentrations of $\alpha$-pinene in capillary blood at the end of exposure to $(+)-\alpha$-pinene at concentrations of 10,225 , and $450 \mathrm{mg} / \mathrm{m}^{2}$ and at the end of exposure to $(-)-a$-pinene at a concentration of $450 \mathrm{mg} / \mathrm{m}^{3}(2 \mathrm{~h}$, $50 \mathrm{~W}$ ) as a function of the total $\alpha$-pinene uptake. The mean values and standard deviations for eight persons are given.
$10 \mathrm{mg} / \mathrm{m}^{3}$ the relative uptake was much lower. Possible reasons are absorption in the airways and in the air regulator during inhalation and thereafter desorption during exhalation. This phenomenon was not seen during the exposure to the higher concentrations because the concentration of desorbed $\alpha$-pinene was negligible in the exhaled air. Although efforts were made to solve it, this problem remained. 


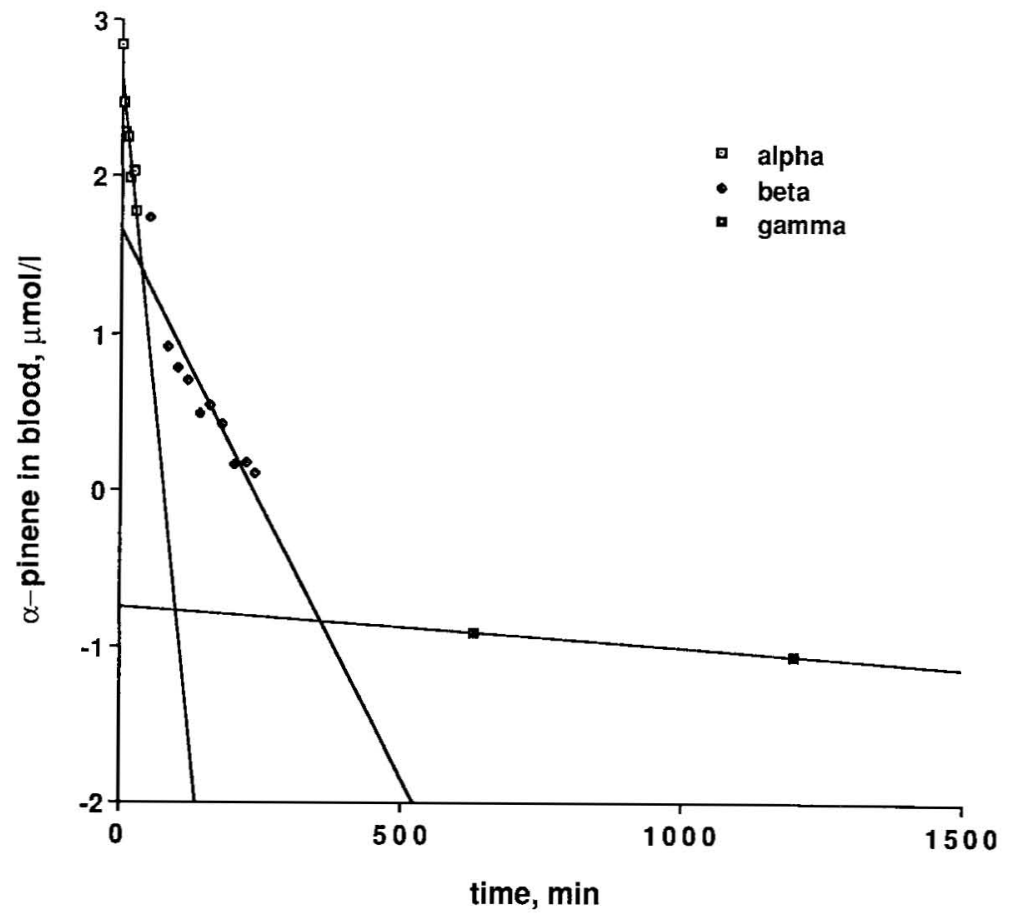

Figure 3. Concentrations of $\alpha$-pinene in capillary blood after the end of the $\alpha$-pinene exposure at $450 \mathrm{mg} / \mathrm{m}^{3}(2 \mathrm{~h}, 50$ W). The phases are expressed as alpha (the difference between the initial phase and the middle and terminal phases), beta (the difference between the middle phase and the terminal phase), and gamma (the terminal phase).

Table 2. Blood clearance from values measured up to about $4 \mathrm{~h}\left(\mathrm{Cl}_{4 \mathrm{~h}}\right)$ and $21 \mathrm{~h}\left(\mathrm{Cl}_{21 \mathrm{~h}}\right)$ after the termination of exposure and the half-time in blood $\left(t_{1 / 2}\right)$ of $\alpha$-pinene for three phases $(\alpha, \beta$ and $\gamma)$, determined from a $2-h$ inhalation exposure to 450 and $225 \mathrm{mg} / \mathrm{m}^{3}(+)-\alpha-$ pinene and $450 \mathrm{mg} / \mathrm{m}^{3}(-)-\alpha$-pinene during physical exercise at a work load of $50 \mathrm{~W}$.

\begin{tabular}{|c|c|c|c|c|c|c|c|c|c|c|}
\hline \multirow{3}{*}{ Exposure level } & \multirow{2}{*}{\multicolumn{2}{|c|}{$\underset{\left(I \cdot h^{-1} \cdot \mathrm{kg}^{-1}\right)}{\mathrm{Cl}_{4 h}}$}} & \multirow{2}{*}{\multicolumn{2}{|c|}{ 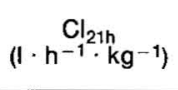 }} & \multicolumn{6}{|c|}{$t_{1 / 2}(\min )$} \\
\hline & & & & & \multicolumn{2}{|c|}{$\alpha$} & \multicolumn{2}{|c|}{$\beta$} & \multicolumn{2}{|c|}{$\gamma$} \\
\hline & Mean & SD & Mean & SD & Mean & SD & Mean & SD & Mean & $\overline{S D}$ \\
\hline \multicolumn{11}{|l|}{$(+)-a$-pinene } \\
\hline $\begin{array}{l}450 \mathrm{mg} / \mathrm{m}^{3} \\
225 \mathrm{mg} / \mathrm{m}^{3}\end{array}$ & $\begin{array}{l}1.40 \\
1.32\end{array}$ & $\begin{array}{l}0.31 \\
0.30\end{array}$ & $\begin{array}{l}1.09 \\
\cdots\end{array}$ & 0.20 & $\begin{array}{l}4.8 \\
\cdots\end{array}$ & 1.5 & $\begin{array}{l}38 \\
\cdots\end{array}$ & 8.2 & $\begin{array}{c}695 \\
\cdots\end{array}$ & 240 \\
\hline \multicolumn{11}{|l|}{$(-1-\alpha$-pinene } \\
\hline $450 \mathrm{mg} / \mathrm{m}^{3}$ & 1.40 & 0.26 & 1.16 & 0.24 & 5.6 & 1.3 & 40 & 12 & 555 & 200 \\
\hline
\end{tabular}

The concentration of $\alpha$-pinene in arterial blood increased linearly with increasing dose (figure 2 ) and therefore indicated that the capacity of the liver to metabolize $\alpha$-pinene is not exceeded within this dose interval. No significant differences in uptake, distribution, or elimination were found for $(+)-\alpha$-pinene and $(-)-\alpha$-pinene.

The relatively high clearance of $\alpha$-pinene observed in this study indicates that $\alpha$-pinene is readily metabolized. The clearance value was of the same magnitude as those obtained in similar exposure situations for easily metabolized solvents such as styrene and toluene $(14,15)$. The blood concentrations from the lower exposure levels, 225 and $10 \mathrm{mg} / \mathrm{m}^{3}$, were below the detection limit $4 \mathrm{~h}$ after exposure, and, to aid comparisons of the clearance from the blood at different exposure levels, the $\mathrm{Cl}_{4 \mathrm{~h}}$ was calculated. Since for $\mathrm{Cl}_{4 \mathrm{~h}}$ the terminal phase(s) was (were) neglected, the AUC was underestimated, and the clearance was thus somewhat overestimated. The value including the $\gamma$ phase, $\mathrm{Cl}_{21 \mathrm{~h}}$, was more accurate but may also have been overestimated for the same reason. The $\mathrm{Cl}_{21 \mathrm{~h}}$ value $\left(1.1 \mathrm{l} \cdot \mathrm{h}^{-1} \cdot \mathrm{kg}^{-1}\right)$ was somewhat lower than the total blood flow through the liver (about $1.4 \mathrm{l} \cdot \mathrm{h}^{-1} \cdot \mathrm{kg}^{-1}$ ) at a work load of $50 \mathrm{~W}$ (17). The hepatic extraction ratio, $\mathrm{E}_{\mathrm{h}}=0.8$, indicates high but not complete hepatic extraction if no extrahepatic metabolism is assumed. The long half-time of $\alpha$-pinene implies that it would take more than $2 \mathrm{~d}$ for the body to be almost completely cleared of $\alpha$-pinene (estimated as $5 \times \mathrm{t}_{1 / 2}$ ).

The total elimination of unchanged $\alpha$-pinene via the lungs after the end of exposure was about $7.6 \%$ (table 1). The renal elimination of unchanged $\alpha$-pinene was low. Less than $0.001 \%$ of the dose was excreted 


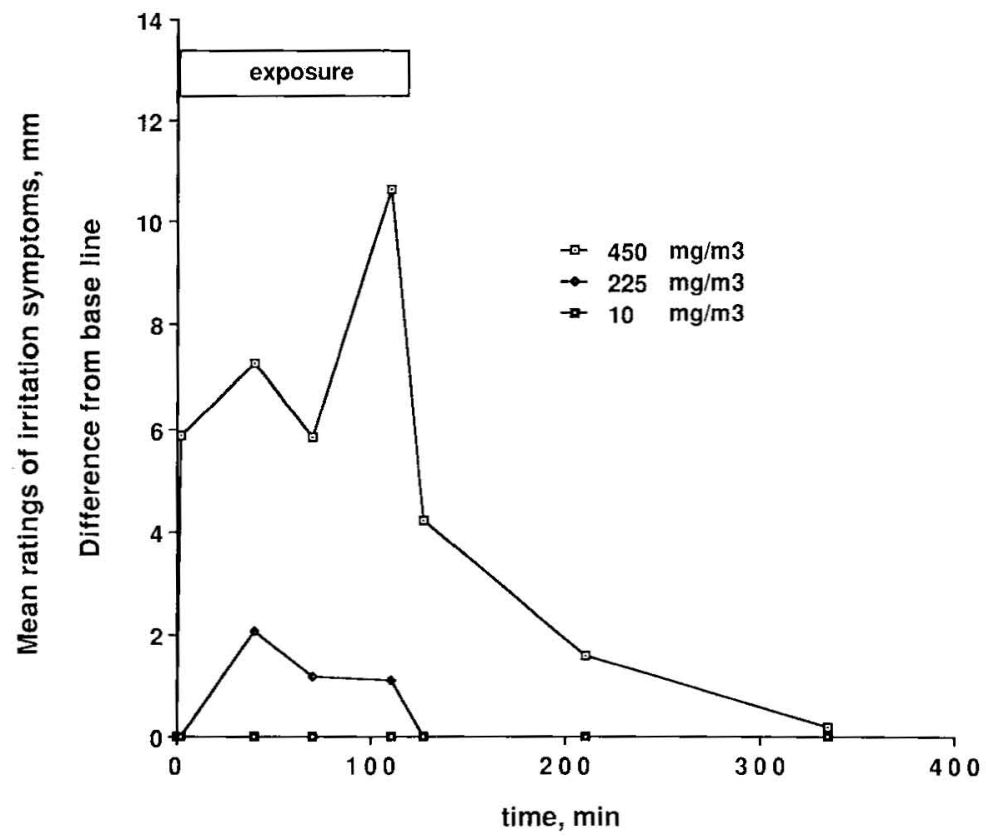

Figure 4. Symptom indices of irritation over exposure and time for $\alpha$-pinene at three different exposure levels $(2 \mathrm{~h}$, $50 \mathrm{~W}$ ). The indices are expressed as the mean of the difference between the base-line measurement and the ratings on each occasion. The mean values for the irritation ratings of five persons are given.

Table 3. Preexposure lung function values and the percentage of change $30 \mathrm{~min}$ after a 2-h inhalation exposure (50 W) to $(+)-\alpha$-pinene at concentrations of 10 and $450 \mathrm{mg} / \mathrm{m}^{3}$. (FEV ${ }_{10}=$ forced expiratory volume in $1 \mathrm{~s}, V C=$ vital capacity, $R V=r e s i d u a l$ volume, $\mathrm{PEF}=$ peak expiratory flow, $\mathrm{MEF}_{50}=$ mean expiratory flow at $50 \%$ of the $\mathrm{VC}$, sGaw $=$ conductance, Raw $=$ resistance)

\begin{tabular}{|c|c|c|c|c|c|c|c|c|c|c|c|c|c|c|}
\hline & \multicolumn{2}{|c|}{$\begin{array}{c}\mathrm{FEV}_{1.0} \\
(1)\end{array}$} & \multicolumn{2}{|c|}{$\begin{array}{l}\text { vc } \\
\text { (I) }\end{array}$} & \multicolumn{2}{|c|}{$\begin{array}{l}\text { RV } \\
\text { (I) }\end{array}$} & \multicolumn{2}{|c|}{$\begin{array}{l}\text { PEF } \\
\text { (I) }\end{array}$} & \multicolumn{2}{|c|}{$\begin{array}{c}\mathrm{MEF}_{50} \\
\left(\mid \mathrm{l} / \mathrm{s}^{1}\right)\end{array}$} & \multicolumn{2}{|c|}{$\begin{array}{l}\text { sGaw } \\
(1 / \mathrm{kPa} / \mathrm{s})\end{array}$} & \multicolumn{2}{|c|}{$\underset{(\mathrm{kPaxs} / \mathrm{l})}{\operatorname{Raw}}$} \\
\hline & Mean & SD & Mean & SD & Mean & SD & Mean & SD & Mean & SD & Mean & SD & Mean & SD \\
\hline $\begin{array}{l}\text { Preexposure } \\
\text { value }\end{array}$ & 4.8 & 0.6 & 6.6 & 0.7 & 2.9 & 1.1 & 12.7 & 2.8 & 5.2 & 1.1 & 2.1 & 1.0 & 0.14 & 0.05 \\
\hline $\begin{array}{l}\text { Percentage of } \\
\text { change after } \\
30 \mathrm{~min}\end{array}$ & & & & & & & & & & & & & & \\
\hline $\begin{array}{l}10 \mathrm{mg} / \mathrm{m}^{3} \\
450 \mathrm{mg} / \mathrm{m}^{3}\end{array}$ & $\begin{array}{l}0.5 \\
3.4\end{array}$ & $\begin{array}{l}0.1 \\
4.7\end{array}$ & $\begin{array}{r}-0.1 \\
0.8\end{array}$ & $\begin{array}{c}13 \\
6.4\end{array}$ & $\begin{array}{r}-5.8 \\
1.5\end{array}$ & $\begin{array}{l}24 \\
26\end{array}$ & $\begin{array}{c}0.4 \\
3.2\end{array}$ & $\begin{array}{l}13 \\
12\end{array}$ & $\begin{array}{l}1.7 \\
5.5\end{array}$ & $\begin{array}{l}5.6 \\
7.6\end{array}$ & $\begin{array}{l}16 \\
5.4\end{array}$ & $\begin{array}{l}55 \\
49\end{array}$ & $\begin{array}{l}-25 \\
-25\end{array}$ & $\begin{array}{l}23 \\
26\end{array}$ \\
\hline
\end{tabular}

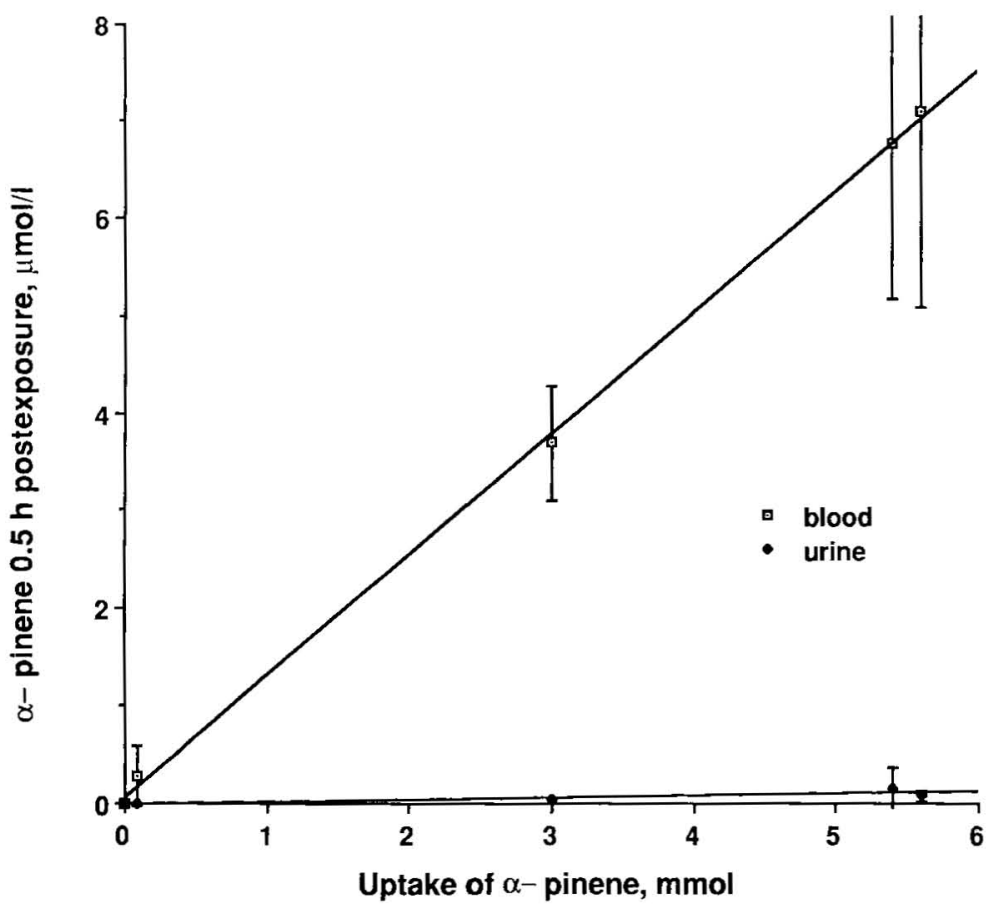

Figure 5. Concentrations of $\alpha$-pinene in capillary blood and in urine $0.5 \mathrm{~h}$ after the termination of exposure to $(+)$ a-pinene at concentrations of 10,225 , and $450 \mathrm{mg} / \mathrm{m}^{3}$ and after the termination of (-)-a-pinene at a concentration of $450 \mathrm{mg} / \mathrm{m}^{3}(2 \mathrm{~h}, 50 \mathrm{~W})$ as a function of the total $\alpha$-pinene uptake. The mean values and standard deviations for eight persons are given. 
in the urine during the first $30 \mathrm{~min}$ after the exposure (table 1), and after this period the concentrations in the urine were below the detection limit. A low urinary elimination of unchanged solvent is to be expected from the low in vitro partition coefficient of 0.008 between water and blood (4). The average concentration of $\alpha$-pinene indicated linear kinetics for the urine, as well as for the blood, but the individual variations were high (figure 5).

The ratings of symptoms were divided into irritation symptoms and CNS effects. Although the intensity of the ratings was low, only about $10 \%$ of the scale, the ratings of irritation indicated a statistically significant exposure-response relationship, while no exposure-response relationship was found for the CNS effects.

Exposure to $\alpha$-pinene did not give rise to acute changes in lung function during the exposure in the chamber or $20 \mathrm{~min}$ after exposure. The tendency was towards increased airway diameters rather than the opposite. Thus it is unlikely that short-time exposure to $\alpha$-pinene causes acute bronchoconstriction in young healthy subjects who have not earlier been exposed to terpenes.

This investigation was designed to study the toxicokinetics of $\alpha$-pinene. Because of the limited number of subjects it was not possible to evaluate the results in the rating of symptoms and the nonsignificant results from the measurements of pulmonary function. Further studies with more subjects and spirometric measurements made during exposure may be necessary for adequate assessment of the acute effects of $\alpha$-pinene exposure.

\section{Acknowledgments}

The authors are grateful to Dr G Johanson for his critical review of the manuscript and to Ms L Ernstgård and Ms E Gullstrand for their skillful technical assistance.

We are also grateful for the financial support received from the Swedish Work Environment Fund (grant no 88-1415).

\section{References}

1. Grimm W, Gries H. Turpentine. In: L Parmeggiani, ed. Encyclopaedia of occupational safety and health, Geneva: International Labour Office, 1983:2229.
2. Hedenstierna G, Alexandersson R, Wimander K, Rosen G. Exposure to terpenes: effects on pulmonary function. Int Arch Occup Environ Health 1983;51:191-8.

3. Lindberg E. Exposition för sågångor: samband mellan exposition och besvär samt mellan exposition och vissa lungfunktionsvariabler [Exposure to wood-vapors: correlation between exposure and some pulmonary function variables]. Stockholm: Arbetarskyddsverket, 1979. (Arbete och hälsa 1979:27.) (English abstract.)

4. Falk A, Gullstrand E, Löf A, Wigaeus-Hjelm E. Liquid/ air partition coefficients of four terpenes. $\mathrm{Br} \mathrm{J}$ Ind Med 1990;47:62-4.

5. Sandmeyer EE. Acyclic hydrocarbons. In: Clayton GD, Clayton FE, ed. Patty's industrial hygiene and toxicology; vol 2. 3rd ed. London: John Wiley and Sons Inc, 1983:3243-6.

6. von Schäfer R, Schäfer W. Die percutan Resorption verschiedener Terpene-Menthol, Campher, Limonen, Isobornylacetat, $\alpha$-pinen-aus Badezusätzen. Arzneimi Helforschung 1982;32(1):56-8.

7. Sperling F, Marcus WL, Collins C. Acute effects of turpentine vapor on rats and mice. Toxicol Appl Pharmacol 1967;10:8-20.

8. Savolainen H, Pfäffli P. Effects of long-term turpentine inhalation on rat brain protein metabolism. Chem Biol Interact 1978;21:271-276.

9. Köppel C, Tenczer J, Tönnesmann U, Schirop T, Ibe $\mathrm{K}$. Acute poisoning with pine oil-metabolism of monoterpenes. Arch Toxicol 1981;49:73-8.

10. Brun R. Epidemiology of contact dermatitis in Geneva (1000 cases). Contact Dermatitis 1975;1:214-7.

11. Dooms-Goossens A, Degreef $\mathbf{H}$, Holvoet $\mathbf{C}$, Maertens M. Turpentine-induced hypersensitivity to peppermint oil. Contact Dermatitis 1977;3:304-8.

12. Hedenstierna G, Alexandersson R, Rosén G, Wimander $\mathrm{K}$, Randma E. Subjektiva besvär och lungfunktion vid yrkesmässig exponering för sågångor [Symptoms and pulmonary function after exposure to wood-vapors at work]. Solna (Sweden): National Institute of Occupational Health, 1984. (Arbete och Hälsa 1984:8.) (English abstract.)

13. Rowland M, Tozer TN. Clinical pharmacokinetics: concepts and applications. 2nd ed. Philadelphia, PA: Lea \& Febiger, 1989.

14. Carlsson A. Exposure to toluene: uptake, distribution and elimination in man. Scand $\mathbf{J}$ Work Environ Health 1982;8:43-55.

15. Wigaeus $\mathbf{E}$, Löf $\mathbf{A}$, Bjurström $\mathbf{R}$, Byfält Nordqvist $\mathbf{M}$. Exposure to styrene: uptake, distribution, metabolism and elimination in man. Scand J Work Environ Health 1983;9:479-88.

16. Sato A, Nakajima T. Partition coefficients of some aromatic hydrocarbons and ketones in water, blood and oil. Br J Ind Med 1979;36:231-4.

17. Åstrand I. Effect of physical exercise on uptake, distribution and elimination of vapors in man. In: FiserovaBergerova V, ed. Modeling of inhalation exposure to vapors: uptake, distribution and elimination. Boca Raton, FL: CRC Press Inc, 1983:107-33.

Received for publication: 25 January 1990 